\title{
Rent Sharing as a Driver of the Glass Ceiling effect
}

\author{
Alessia Matano \\ Universitat de Barcelona, University of Rome “La Sapienza \\ Paolo Naticchioni \\ University of Cassino, University of Rome "La Sapienza”, CeLEG-Luiss
}

May 2012

\begin{abstract}
In this paper we show that rent sharing plays a role in explaining the glass ceiling effect. We make use of a unique employer-employee panel database for Italy from 1996 to 2003, which allows controlling for observed individual and firm heterogeneity and for collective bargaining. Moreover, by means of IV quantile fixed effects estimates we can cope with unobserved heterogeneity and endogeneity. A discussion of different explanations is provided.
\end{abstract}

Keywords: Rent Sharing, Gender Wage Gap, Glass Ceiling, Quantile Regressions. JEL Classification: C33, J16, J31, J41, L25. 


\section{Introduction}

The glass ceiling effect is one of the stylized fact concerning the gender pay gap. One of the pioneering work is Albrecht, Bjorklund and Vroman (2003) that use quantile regressions and Swedish data finding an increasing gender pay gap along the wage distribution. Other papers have then extended this finding to most of the OECD countries (Arulamapalan et al. 2007). Although the glass ceiling phenomenon is observed in most OECD countries, the understanding of the reasons behind it represents an open field of research (Booth, 2007), with relatively few papers testing explanations from an empirical point of view (De la Rica et al., 2010, Bertrand and Hallock, 2001, among others). ${ }^{1}$

In this paper we propose a new explanation for the glass ceiling effect, investigating whether men and women differ in their efficacy to extract rents from firms, and whether this difference increases along the wage distribution. We make use of a unique employer-employee panel database for Italy.

The relation between rent-sharing and the gender wage gap has been previously investigated by Nekby (2003), both at the conditional mean and along the wage distribution. ${ }^{2}$ Nonetheless, this paper did not properly control for unobserved heterogeneity and endogeneity, issues that have been proved to be crucial in the estimation of rent sharing (Abowd and Lemieux, 1993, Card et al., 2010). We can cope with these issues by using IV quantile fixed effects estimates.

\section{Data Description}

We make use of a unique panel version of the administrative employer-employee database provided by INPS (Italian Social Security Institute). The sample units are industrial and service dependent workers, both part-time (converted in full-time equivalent) and full-time, in standard labour market contracts (blue collars, white collars and managers), aged between 15 and 64 (when they first enter in the

\footnotetext{
${ }^{1}$ Bertrand and Hallock (2001) is actually related to a slightly different literature that investigates the behaviour of selected group of workers, such as CEO and top executives.

2 Also Plasman et al. (2004) investigate the impact of rent sharing on the gender pay gap. However, they do not address the glass ceiling phenomenon since their analysis is restricted to the conditional mean.
} 
database), with al least two observations in the panel. We merge the INPS dataset with the AIDA database, which includes information on the balance sheet of (capitalowned) firms from 1996 to 2003, in such a way restricting the sample to workers employed in capital owned firms. ${ }^{3}$

Our main independent variable is quasi-rent per worker, i.e. the rents per worker evaluated at the opportunity cost of labour, which is defined as the revenue per worker (operative income -which equals to net profits- plus the wage bill), minus the alternative wage, as in Van Reenen (1996).

An important value added of our matched employer-employee database concerns the way of computing the alternative wage, since it allows controlling accurately for the collective bargaining, i.e. for the part of bargaining that takes place at national/sectoral level and that is not related to individual negotiation. In Italy the collective bargaining is characterized by two levels: a first centralized (national) level where minimum wages for all occupations are set in all industries; a second decentralized level where the employer and employees (individually or at the firm/territorial level) can bargain over wages and other working conditions. To control properly for the first national level of bargaining we introduce in our estimation the minimum wage corresponding to the worker's specific national contract and, within the contract, to the specific occupation ("livello di inquadramento"), as in Card et al. (2010). This turns out to be a more reliable measure of the alternative wage with respect to using average industrial wages. Since in Italy there are more than 200 national contracts, we restrict our sample to the greatest 26 national contracts ( $80 \%$ of the total sample), to have enough variability within each contract-occupation cell.

Table 1 shows the descriptive statistics by gender of the variables of the analysis.

\footnotetext{
${ }^{3}$ Data on profits are deflated using the valued added deflator (base year, 2002). Further, we clean our data as in the following: we drop observations for which the difference in absolute value between the firm size reported in AIDA and the firm size reported in INPS was higher than 200 (so doing the correlation between firm size in the two databases is 99.95), as well as extreme observations below (above) the $1^{\text {st }}\left(99^{\text {th }}\right)$ percentile of wages and profits per employee; we also drop outliers with respect to the yearly growth rate of wages and profits per employee.
} 


\section{Econometric specifications and Results}

Since our analysis concerns the whole wage distribution, we make use of the quantile regression approach. The baseline specification is the following:

$$
\begin{aligned}
\ln \left(w_{i, t}\right)= & \alpha_{\theta}+\chi_{\theta}{ }^{*} \ln M W_{c(i, t)}+B_{\theta}^{\prime}{ }^{*} I_{-} C_{\text {Char }}{ }_{i, t}+\beta_{\theta}{ }^{*} \ln \text { Firmsize }_{j(i, t)}+\gamma_{1, \theta}{ }^{*} \ln \text { Quasi Rents }_{j(i, t)}+ \\
& +\varphi_{s, \theta}+\lambda_{a, \theta}+\delta_{t, \theta}+\varepsilon_{i, t, \theta}
\end{aligned}
$$

where $\theta$ refers to the percentile, $i$ to individuals, $j(i, t)$ to the firm where the worker $i$ is employed at time $t, c(i, t)$ to the national contract the worker is subject to, $s$ to industry. The dependent variable in our regressions is the $(\log )$ real gross weekly wage. The term I_Char ${ }_{i, t}$ is a set of observed individual characteristics (age, age squared, tenure and occupation dummy). $M W_{c(i, t)}$ is the national contract minimum wage that controls for first level bargaining. QuasiRents $j_{j(i, t)}$ is quasi-rent per employee. Firmsize $e_{i, t}$ is the proxy for firm heterogeneity, while $\varphi_{s}, \lambda_{a}, \delta_{t}$ are industry, area (five macro-areas in Italy: Northwest, Northeast, Centre, South and Islands) and time dummies respectively. All the variables of interest are in logarithms and therefore we estimate elasticities.

The first step of the analysis is to carry out cross sectional quantile estimates at the $10^{\text {th }}, 25^{\text {th }}, 50^{\text {th }}, 75^{\text {th }}$ and $90^{\text {th }}$ percentiles, separately for men and women, controlling for observed heterogeneity of workers and firms. From Table 2 it is possible to note that rent sharing estimates are greater for men, and for both men and women they are slightly increasing along the wage distribution. However, using cross sectional regressions we cannot control for the unobserved heterogeneity of workers. Hence, we implement quantile fixed effect estimates, as proposed by Koenker (2004). Estimates in Table 3 prove that, as expected, when controlling for the individual unobserved heterogeneity rent sharing estimates strongly dampen, consistently with the sorting literature (Mion and Naticchioni, 2009) and with the rent sharing literature (Card et al., 2010). Moreover, in fixed effects the estimates are basically flat both for men and women and still higher for men than for women.

The last step in order to derive unbiased estimates is to address the endogeneity due to the likely simultaneous determination of wages and profits and to measurement errors, endogeneity that can cause a severe underestimation of rent 
sharing (Van Reenen, 1996, Card et al. 2010). Since we are working in a quantile framework we apply a very recent methodology developed by Galvao and MontesRojas (2009), Galvao (2011) and Harding and Lamarche (2009). This procedure is an extension of the IV quantile procedure of Chernozhukov and Hansen (2008) that allows for the inclusion of fixed effects as introduced in Koenker (2004).

As instrument for firm profits we exploit the idea developed in Card et al. (2010) by using for each firm in a given province the average of current total real sales per employee of firms located in all other Italian provinces but operating in the same three-digit sector. ${ }^{4}$ The identifying assumption is that national industry demand shocks affect firm level profitability but have no direct effect on local labour conditions. $^{5}$

Results are shown in Table 4. As expected, the degree of underestimation of the fixed effects estimates is substantial. As for men, rent elasticities are quite stable along the wage distribution, ranging from $5.9 \%$ at the $10^{\text {th }}$ percentile to $4.4 \%$ at the $90^{\text {th }}$ percentile. For women, the extent of rent sharing is again lower than for men. Further, it is basically stable from the $10^{\text {th }}$ percentile to the median $(3.8 \%$ and $3 \%$ respectively), while it falls substantially at the $90^{\text {th }}$ percentile $(1.6 \%)$. These findings strongly suggest that, once controlling for unobserved heterogeneity and endogeneity, the rent sharing impact is such to increase the gender wage gap along the wage distribution, contributing to generate a glass ceiling effect. ${ }^{6}$

\footnotetext{
${ }^{4}$ To compute these averages we use weights equal to the inverse of distances between provinces: more weight is given to closer provinces. The weighing procedure increases the explicative power of the instrument. Nonetheless, similar results apply even when weights do no change with distance.

5 The estimation is carried out simultaneously on three percentiles $\left(10^{\text {th }}, 50^{\text {th }}, 90^{\text {th }}\right)$ for computational reasons. Further, this estimation technique does not allow testing the weakness of instruments. The only possible check is to implement a standard IV fixed effects estimation and look at the F-statistic of the first stage. In our case the F-statistics are statistically significant and higher than the threshold value of 10 for both gender categories.

${ }^{6}$ As a robustness check, instead of using the individual minimum wage as a measure of the alternative wage, we make use of a more standard measure used in the literature, the industrial wage (as in Van Reenen, 1996). This is computed as the average of individual minimum wages at the national contract level (each national contract roughly corresponds to a different industry). Results are similar from a qualitative point of view. In particular, estimates are still decreasing along the wage distribution both for men and women, with a more substantial drop for women at the top of the distribution (from 0.03 at the $10^{\text {th }}$ percentile to 0.01 at the $90^{\text {th }}$ percentile) than for men (from 0.08 to 0.07 ), confirming a widening of the gender wage gap at the 90th percentile.
} 
To characterize further our results we analyze other factors that might play a role in explaining the differences in the rent sharing effect on gender pay gap. First, we consider a possible sorting of women into less profitable firms, pointing out that in our data the share of women is basically stable along the distribution of firm profits: women are not under represented in firms with high profits. ${ }^{7}$ Second, we take into account a possible occupation segregation of women. In Figure 1 we show that the distribution of minimum wages settled at the national level, which represent an excellent proxy for job quality, is basically the same between men and women from the median to the top of the wage distribution. ${ }^{8}$ Hence, since selection into firms and occupations do not differ much between men and women, our findings support explanations for the glass ceiling effect based on the fact that women either cannot or do not want to extract the same amount of rents with respect to men. This might be related to different explanations. In the case where women 'cannot' extract more rents one might think either to employer discrimination, related mainly to women's lower mobility and lower outside option (Manning, 2003), or to different bargaining power between men and women due to cultural differences ('women do not ask', as in Booth, 2007). In the case where women 'do not want' to extract more rents, it might be the case that women at the top of the wage distribution prefer to bargain over other dimensions of benefits rather than extra wage premia, more in line with their familiar duties (for instance flexible working time).

These findings are consistent from a qualitative point of view to those of De La Rica et al. (2010), who find that the gender pay gap takes place mainly in the part of compensations associated to performance pay schemes, especially in the upper tail of the distribution, i.e. glass ceiling effect. Their findings support an explanation based on the existence of monopsonistic features, possibly related to women's lower

\footnotetext{
${ }^{7}$ Dividing the observations in quartiles of the firm profits distribution, the share of women is about $34 \%$ if the first quartile, $28 \%$ in the second, $26 \%$ in the third, and $29 \%$ in the forth.

${ }^{8}$ Note that by using the INPS database we are not able to control for another relevant issue, the selection of women concerning the choice of participating in the labour market, since we do not have inactive individuals in the database. However, it is also important to stress that participation decisions are more an issue for unskilled women, since skilled women (at the $90^{\text {th }}$ percentile) have a much higher opportunity cost. For this reason, we argue that while self selection in participation decisions plays in general a role for women, this effect should be less important for skilled women, which represent the focus of our analysis. Furthermore, there are also methodological difficulties in introducing participation decisions: to the best of our knowledge there is no methodology allowing integrating self selection issues into an IV quantile fixed effect framework.
} 
mobility due to their attachment to household tasks (Manning, 2003). Our approach differs from a performance pay approach since we isolate the impact of firm profits and rent sharing on the gender wage gap, while not considering the other component of performance pay ${ }^{9}$. It is anyway interesting that two similar but different approaches provide analogous explanations of the glass ceiling phenomenon.

\section{Conclusions}

Few explanations are provided for the glass ceiling effect. In this paper we make use of a unique matched employer-employee database to show that even after controlling for first level bargaining, sorting and endogeneity, there is a different degree of rent sharing between men and women that increases along the wage distribution, entailing a glass ceiling effect. A discussion of different explanations is provided.

\footnotetext{
${ }^{9}$ In fact, performance pay schemes might be related to firm profits as well as to various other features, such as individual incentives adopted by firms that are not necessarily related to firm profits, especially in the short term.
} 


\section{References}

Abowd J., Lemieux T., (1993), “The effects of Product Market Competition on Collective Bargaining Agreements: The case of Foreign Competition In Canada", Quarterly Journal of Economics, vol.108, pp.983-1014.

Albrecht, J., Bjorklund, A., and Vroman, S., (2003), "Is there a Glass Ceiling in Sweden?" Journal of Labour Economics, vol.21, n.1, pp.145-177.

Arulampalam W., Booth A.L., and Bryan, M.L., (2007), "Is there a glass ceiling in Europe? Exploring the gender pay gap across the wages distribution". Industrial and Labor Relations Review, vol.60(2), pp.163-186.

Bertrand, M. \& K. Hallock (2001), "The Gender Gap in Top Corporate Jobs", Industrial and Labor Relations Review, 55, 3-21.

Booth A.L., (2007), "The Glass Ceiling in Europe: Why are Women Doing Badly in the Labour Market?", Swedish Economic Policy Review, 14, pp.121-144.

Card, D., Devicienti, F., Maida, A., (2010), "Rent Sharing, Hold Up and Wages: Evidence of Matched Panel Data", NBER Working Paper No. 16192.

Chernozhukov, V., Hansen, C. (2008), Instrumental Variable Quantile Regression: A Robust Inference Approach, Journal of Econometrics, 142: 379-398.

De la Rica S., Dolado J., and Sanchez R.V., (2010), "Performance Pay and the Gender Wage Gap: Evidence from Spain”, CEPR Discussion Paper n.7936.

Galvao, A., Montes-Rojas, G. (2009), Instrumental Variables Quantile Regression for Panel Data with Measurement Errors, Department of Economics Discussion Paper Series 09/06, City University London.

Galvao, A. (2011), Quantile Regression for Dynamic Panel Data, Journal of Econometrics, in Press, Corrected Proof, Available online 2 March 2011.

Harding, M., Lamarche, C. (2009), A Quantile Regression Approach for Estimating Panel Data Models Using Instrumental Variables, Economic Letters, 104: 133-135.

Koenker, R. (2004), Quantile Regression for Longitudinal Data, Journal of Multivariate Analysis, 91(1): 74-89.

Manning, A. (2003), Monopsony in Motion, Princeton University Press.

Mion G., Naticchioni P., (2009), "The Spatial Sorting and Matching of Skills and Firms", Canadian Journal of Economics, Canadian Economics Association, vol. 42(1), pages 28-55, February.

Nekby L., (2003) "Gender differences in rent sharing and its implications for the gender wage gap, evidence from Sweden", Economic Letters, vol.81 (403-410).

Plasman R., Rycx F., and Torejow I., (2004), "Rent Sharing and the Gender Wage Gap in Belgium", International Journal of Manpower, vol.25(3), pp.279-299.

Van Reenen J., (1996), “The Creation and Capture of Rents: Wages and Innovation in a Panel of U.K. Companies", Quarterly Journal of Economics, vol.111, pp.195-226.

\section{Acknowledgments}

We thank the research partnership between ISFOL - Area Mercato del Lavoro (Rome) and Dipartimento di Scienze Sociali - University of Rome "La Sapienza" - for access to the databases. We thank Massimiliano Bratti, Francesco Fasani, Giuseppe Ragusa, Pietro Reichlin, Alessandro Sembenelli, Giovanni Sulis and Giovanna Vallanti for their suggestions, as well as the participants to the RES 2011, AIEL 2010, ICEEE 2011 and 
CeLEG-Luiss seminars. Alessia Matano also thanks the Spain's Ministerio de Ciencia e Innovación (VI Plan Nacional de Investigación Científica, Desarrollo e Innovación Tecnológica 2008-2011) for the support received through the action ECO2010-16006. 
TABLES AND FIGURES

\begin{tabular}{l|rr|rr}
\hline \multicolumn{5}{c}{ Table 1: Descriptive Statistics of the Variables of the Analysis } \\
\hline \multicolumn{4}{|c}{ Men } & \multicolumn{3}{c}{ Women } \\
\hline Variable & Mean & Std.Dev. & Mean & Std.Dev. \\
\hline Log Real Weekly Wage & 6.02 & 0.28 & 5.91 & 0.25 \\
Log Real Minimum Weekly Wage & 5.53 & 0.12 & 5.52 & 0.13 \\
Age & 37.00 & 9.79 & 35.82 & 9.51 \\
Age Squared & 1464.65 & 765.47 & 1373.61 & 728.73 \\
Tenure 0-1 & 0.35 & 0.48 & 0.35 & 0.48 \\
Tenure 2-9 & 0.48 & 0.50 & 0.48 & 0.50 \\
Tenure >9 & 0.17 & 0.37 & 0.17 & 0.38 \\
Blue Collar & 0.71 & 0.45 & 0.44 & 0.50 \\
White Collar and Manager & 0.29 & 0.45 & 0.56 & 0.50 \\
Log Firm Size & 4.41 & 1.49 & 4.42 & 1.54 \\
Log Quasi Rent per Employee & 2.76 & 0.91 & 2.62 & 1.05 \\
dNorth East & 0.30 & 0.46 & 0.30 & 0.46 \\
dNorth West & 0.41 & 0.49 & 0.46 & 0.50 \\
dCentre & 0.16 & 0.37 & 0.16 & 0.37 \\
dSouth & 0.10 & 0.30 & 0.06 & 0.23 \\
dIsland & 0.04 & 0.19 & 0.02 & 0.14 \\
Number of National Contracts & 26 & & 26 & \\
\hline Number of observations & 131,300 & 55,417 & \\
Number of groups & 32,921 & \multicolumn{4}{c}{14,482} & \\
\hline
\end{tabular}

Source: Panel ISFOL on INPS-AIDA data. 


\begin{tabular}{|c|c|c|c|c|c|}
\hline & q10 & q25 & q50 & q75 & q90 \\
\hline \multicolumn{6}{|c|}{ Men } \\
\hline Ln Quasi Rent & $0.034^{* * *}$ & $0.039 * * *$ & $0.043^{* * *}$ & $0.046^{* * *}$ & $0.048^{* * *}$ \\
\hline Ln Minimum Wage & $1.414^{* * *}$ & $1.539 * * *$ & $1.667^{* * *}$ & $1.723^{* * *}$ & $1.659^{* * *}$ \\
\hline Age & $0.010 * * *$ & $0.010^{* * *}$ & $0.010^{* * *}$ & $0.011^{* * *}$ & $0.014^{* * *}$ \\
\hline Age Squared & $-0.000 * * *$ & $-0.000 * * *$ & $-0.000 * * *$ & $-0.000 * * *$ & $-0.000 * * *$ \\
\hline Tenure 2-9 & $0.041^{* * *}$ & $0.030^{* * *}$ & $0.020 * * *$ & $0.011^{* * *}$ & $0.008^{* * *}$ \\
\hline Tenure $>10$ & $0.075^{* * *}$ & $0.057^{* * *}$ & $0.038^{* * *}$ & $0.028 * * *$ & $0.021^{* * *}$ \\
\hline White Collar and Manager & $0.031^{* * *}$ & $0.037^{* * *}$ & $0.058^{* * *}$ & $0.086^{\star * *}$ & $0.123^{* * *}$ \\
\hline ln Firm Size & $0.019^{* * *}$ & $0.018^{* * *}$ & $0.016^{* * *}$ & $0.012^{* * *}$ & $0.009 * * *$ \\
\hline Const & $-2.513^{* * *}$ & $-3.127^{* * *}$ & $-3.741^{* * *}$ & $-3.970 * * *$ & $-3.539 * * *$ \\
\hline $\mathbf{R}^{2}$ & 0.36 & 0.38 & 0.40 & 0.42 & 0.42 \\
\hline \multicolumn{6}{|c|}{ Women } \\
\hline Ln Quasi Rent & $0.018^{* * *}$ & $0.022^{* * *}$ & $0.026^{* * *}$ & $0.028^{* * *}$ & $0.028^{* * *}$ \\
\hline Ln Minimum Wage & $1.285^{* * *}$ & $1.373^{* * *}$ & $1.512^{* * *}$ & $1.639 * * *$ & $1.719^{* * *}$ \\
\hline Age & $0.003^{* * *}$ & $0.005^{* * *}$ & $0.005^{* * *}$ & $0.004^{* * *}$ & 0.001 \\
\hline Age Squared & $-0.000^{* * *}$ & $-0.000^{* * *}$ & $-0.000^{* * *}$ & $-0.000 * * *$ & $-0.000 * * *$ \\
\hline Tenure 2-9 & $0.033^{* * *}$ & $0.026^{* * *}$ & $0.016^{* * *}$ & $0.007^{* * *}$ & 0.0000 \\
\hline Tenure $>10$ & $0.061^{* * *}$ & $0.051^{* * *}$ & $0.033^{* * *}$ & $0.018^{* * *}$ & 0.0000 \\
\hline White Collar and Manager & $0.039 * * *$ & $0.034^{* * *}$ & $0.037^{* * *}$ & $0.047^{* * *}$ & $0.075^{* * *}$ \\
\hline ln Firm Size & $0.015^{\star * *}$ & $0.017^{* * *}$ & $0.017^{* * *}$ & $0.016^{* * *}$ & $0.013^{* * *}$ \\
\hline Const & $-1.679 * * *$ & $-2.154^{* * *}$ & $-2.852^{* * *}$ & $-3.457^{* * *}$ & $-3.782^{* * *}$ \\
\hline $\mathbf{R}^{2}$ & 0.35 & 0.39 & 0.43 & 0.44 & 0.43 \\
\hline
\end{tabular}

Notes: ${ }^{* * *}, * *$ and * denote significance at $1 \%, 5 \%$ and $10 \%$ respectevely. Estimates all include area, time, and sector dummies. For Men (Women) 131,300 (55,417) observations for 32,921 $(14,482)$ individuals. 


\begin{tabular}{|c|c|c|c|c|c|}
\hline & $\mathbf{q 1 0}$ & $\mathbf{q 2 5}$ & q50 & q75 & $\mathrm{q90}$ \\
\hline \multicolumn{6}{|c|}{ Men } \\
\hline ln Quasi Rent & $0.014^{* * *}$ & $0.012^{* * *}$ & $0.013^{* * *}$ & $0.014^{\star * *}$ & $0.015^{* * *}$ \\
\hline ln Minimum Wage & $0.981^{* * *}$ & $0.964^{* * *}$ & $0.957^{* * *}$ & $0.973^{* * *}$ & $1.003^{\star \star *}$ \\
\hline Age & $0.009^{* * *}$ & $0.009^{* * *}$ & $0.008^{* * *}$ & $0.006^{*}$ & 0.003 \\
\hline Age Squared & $-0.000^{* * *}$ & $-0.000^{* * *}$ & $-0.000 * * *$ & $-0.000^{* * *}$ & $-0.000^{* * *}$ \\
\hline Tenure 2-9 & $0.042^{* * *}$ & 0.023 & $0.007^{* * *}$ & 0.006 & $-0.019^{*}$ \\
\hline Tenure $>9$ & $0.042^{* * *}$ & 0.021 & $0.003^{* *}$ & -0.009 & $-0.031^{* * *}$ \\
\hline White Collar and Manager & $0.027^{* * *}$ & $0.030^{* * *}$ & $0.0032^{* * *}$ & $0.034^{* \star *}$ & $0.042^{* * *}$ \\
\hline In Firm Size & $0.015^{* * *}$ & $0.014^{* * *}$ & $0.015^{\star * *}$ & $0.014^{* * *}$ & $0.013^{* * *}$ \\
\hline Const & 2.999 & 3.177 & 3.293 & 3.296 & 3.245 \\
\hline \multicolumn{6}{|c|}{ Women } \\
\hline ln Quasi Rent & $0.007^{* * *}$ & $0.006^{* * *}$ & $0.006^{* * *}$ & $0.008^{* * *}$ & $0.008^{* * *}$ \\
\hline In Minimum Wage & $0.950^{* \star *}$ & $0.923^{* * *}$ & $0.920^{\star * *}$ & $0.937^{* * *}$ & $0.978^{* * *}$ \\
\hline Age & -0.001 & 0.0000 & -0.000 & -0.002 & -0.004 \\
\hline Age Squared & $-0.000^{* * *}$ & $-0.000 * * *$ & $-0.000^{* * *}$ & $-0.000^{* * *}$ & $-0.000^{* * *}$ \\
\hline Tenure 2-9 & $0.038^{* * *}$ & $0.025^{*}$ & $0.012^{* * *}$ & 0.0010 & -0.009 \\
\hline Tenure $>\mathbf{1 0}$ & $0.037^{* *}$ & 0.0230 & $0.010^{* *}$ & -0.003 & -0.023 \\
\hline White Collar and Manager & 0.004 & 0.005 & 0.004 & 0.004 & 0.004 \\
\hline In Firm Size & $0.013^{* * *}$ & $0.013^{* * *}$ & $0.013^{* * *}$ & $0.014^{* * *}$ & $0.013^{* * *}$ \\
\hline Const & 4.682 & 4.882 & 4.973 & 4.941 & 4.826 \\
\hline
\end{tabular}

Notes: ***,** and * denote significance at $1 \%, 5 \%$ and $10 \%$ respectevely. Estimates all include area, time, and sector dummies. For Men (Women) 131,300 (55,417) observations for 32,921 $(14,482)$ individuals. 
Table 4: IV Quantile Fixed Effects Regressions of Wages on Quasi Rents

\begin{tabular}{|c|c|c|c|}
\hline & q10 & q50 & q90 \\
\hline \multicolumn{4}{|c|}{ Men } \\
\hline ln Quasi Rent & $0.059^{* * *}$ & $0.047^{* * *}$ & $0.044^{* * *}$ \\
\hline ln Minimum Wage & $0.979 * * *$ & $0.961^{* * *}$ & $1.003^{* * *}$ \\
\hline Age & $0.009^{* * *}$ & $0.007^{* * *}$ & $0.003^{* * *}$ \\
\hline Age Squared & $-0.000^{* * *}$ & $-0.000 * * *$ & $-0.000 * * *$ \\
\hline Tenure 2-9 & $0.042^{* * *}$ & $0.008^{* * *}$ & $-0.017^{* * *}$ \\
\hline Tenure $>9$ & $0.043^{* * *}$ & $0.004^{* * *}$ & $-0.031^{* * *}$ \\
\hline White Collar and Manager & $0.026^{* * *}$ & $0.034^{* * *}$ & $0.046^{* * *}$ \\
\hline ln Firm Size & $0.016^{* * *}$ & $0.016^{* * *}$ & $0.015^{* * *}$ \\
\hline Const & $2.452^{* * *}$ & $2.750^{* * *}$ & $2.734^{* * *}$ \\
\hline \multicolumn{4}{|c|}{ Women } \\
\hline In Quasi Rent & $0.038^{* * *}$ & $0.030^{* * *}$ & $0.016^{* * *}$ \\
\hline ln Minimum Wage & $0.917^{* * *}$ & $0.902^{* * *}$ & $0.992^{* * *}$ \\
\hline Age & $-0.001^{* * *}$ & -0.000 & $-0.004^{* * *}$ \\
\hline Age Squared & $-0.000^{* * *}$ & $-0.000^{* * *}$ & $-0.000^{* * *}$ \\
\hline Tenure 2-9 & $0.037^{* * *}$ & $0.012^{* * *}$ & $-0.008^{* * *}$ \\
\hline Tenure $>\mathbf{1 0}$ & $0.036^{* * *}$ & $0.009 * * *$ & $-0.022^{* * *}$ \\
\hline White Collar and Manager & $0.006^{* * *}$ & $0.004^{* * *}$ & $0.006^{* * *}$ \\
\hline ln Firm Size & $0.014^{* * *}$ & $0.015^{* * *}$ & $0.016^{* * *}$ \\
\hline Const & $3.659^{* * *}$ & $3.878^{* * *}$ & $3.601^{* * *}$ \\
\hline
\end{tabular}

Notes: ${ }^{* * *}, * *$ and * denote significance at $1 \%, 5 \%$ and $10 \%$ respectevely. Estimates all include area, time, and sector dummies. For Men (Women) 131,300 $(55,417)$ observations for $32,921(14,482)$ individuals. 
Figure 1: Distribution of Minimum Wages by Gender

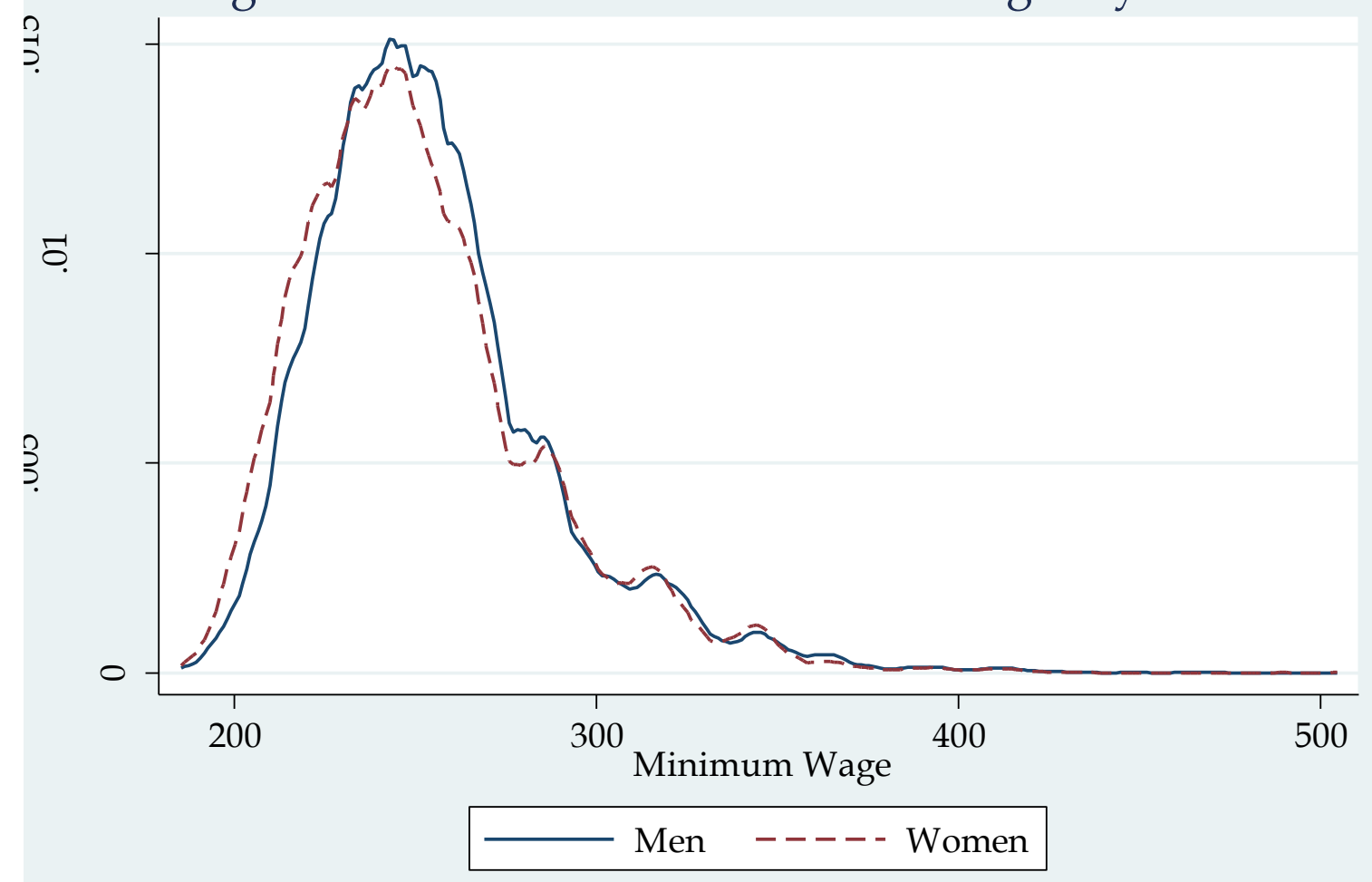

